31）23. 谷口澄夫 : 金昆羅往来筋村落の商策的進展過程 瀬戸内海地域の社会史 的研究所収 (1952) 24. 撮要録 工商之部. 25. 熊沢蕃山：集議外書. 26. 柳田国男氏教示。 27 前揭（20） 28. 撮要録 諸職之部. 29. W. Sombart ; Die drei Nationalökonomien (1930)

\title{
BARE HILLS OF THE OKAYAMA DISTRICT (6)
}

\section{- SOME PROBLEMES ON REGIONAL STRUCTURE-}

\section{Tokuji CHIBA}

1. From the first period of 18th. Century, citizen of Okayama suffered from lack of fuel. This was caused by salt-manufacture which absorbed the fuel from the northern hills where the greater part of of fuels for this fudal teritory was produced. Because at that time the salt-manufacturing developed into a capitalistic industry of comparatively large scale. In spite of the effort of magistrate of Okayama City, fuel could not be supplied to citizen at cheaper price.

2. In 19th. Century, salt manufacture absorbed more and more labour from farming villages and capitalistic salters were in league with the executives of the Okayama Clan to corner in fuel. So the executives could not deal the matter as good as it was hoped by people. In this period, inhabitants of the Setouch Coast and the Okayama Plain bought the fuel secretly cut from the common forests by poor farmers. In old times, there would have been some habits in rural communities of Japan to help the poors by allowing the use of common land or giving something to them. Following these habits the secret hewing made by them also seems to be connived. Thus the hills made up of granitic rocks were increasingly denuded especially in the common forests which were the only source of income for the poors. In addition, these districts have the least precipitation in Japan, which makes the restoration of natural vegetation difficult. Thus some of the denuded hills remain as bare hills in these districts to date. As to fertilizer, these economic and social coditions brought about the same results.

\section{盛岡断層群に就いて*

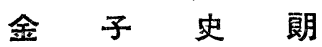

1.はしがき 盛岡と花巻市を結ぶ北上川の西辺に，東向をの急崖列が あつて盛岡断層群と呼ばれ(1)，最近その中央にある上平断尿崖北部で洪積 尿をきる正断層が指摘され(2)，また附近には衝上断屬もうられるといら(3).

* 本稿の要旨は1953年7月の日本地理学会例会で発表した。地理学評馀28卷4号(1955年4月) 
筆者は 1951 年の秋, 花卷附近から北の地域を調查して，数箅所で断犀面を 久たので報告する。香お, 地屬の対比などの目的で, 本地域の南部, 黑沢尻町 周辺を巡検した。本稿を草するに当り御指導を戴的石川教授，町田講師， ならびに中山正民氏に感謝する次第である。

2 ，地啠 調査期間が短く，そのう え火成砕屑岩類が多い地域学ので，ま だ不十分を所も多いが，結果は第 1 図 に示した通りである。調查は 25,000 分の 1 の地形図によつて行つた. 次に 主な観察事項を古い方から時代順にの ベる.

[基盤]栗根山の南, 袖滰沢出合附 近に夕られる変成岩類は, 主にホルン フェルス等からなり，第 3 系の基盤と 考えられる。乙れは花南岩磁（径 $1 \mathrm{~m}$ ) 走多数混える緑色凝灰角碩岩（以下グ リーン・タフと呼ぶ）で不整合に被わ れる. 基盤の走向は大体 $\mathrm{N} 40 \sim 60^{\circ} \mathrm{W}$ でSWへ $80^{\circ}$ 位傾き，北上山地の西辺

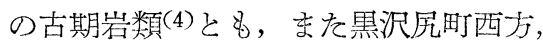
仙人峠附近の第 3 系基盤(5)と夕似を傾 向がある。

第3 系: 〔グリーン・タフ]調查地 域内に最広く分布し，一般に無層理 質塊状で，中・北部ではしばしば花菵 岩・ホルフェルス・古期堆積岩の砕片 を混え，滝名川流域では処により水平 層理をしめすととがある. 本層を調査 地域内の最8下部の，大体同一層準孛 示寸地層として取扱つたが，まだ問題 亿客る点もあうら。

[高井沢累層] 黒森山 $(414 \mathrm{~m})$ 北 東，字高井沢の北向筋壊崖には愿さ

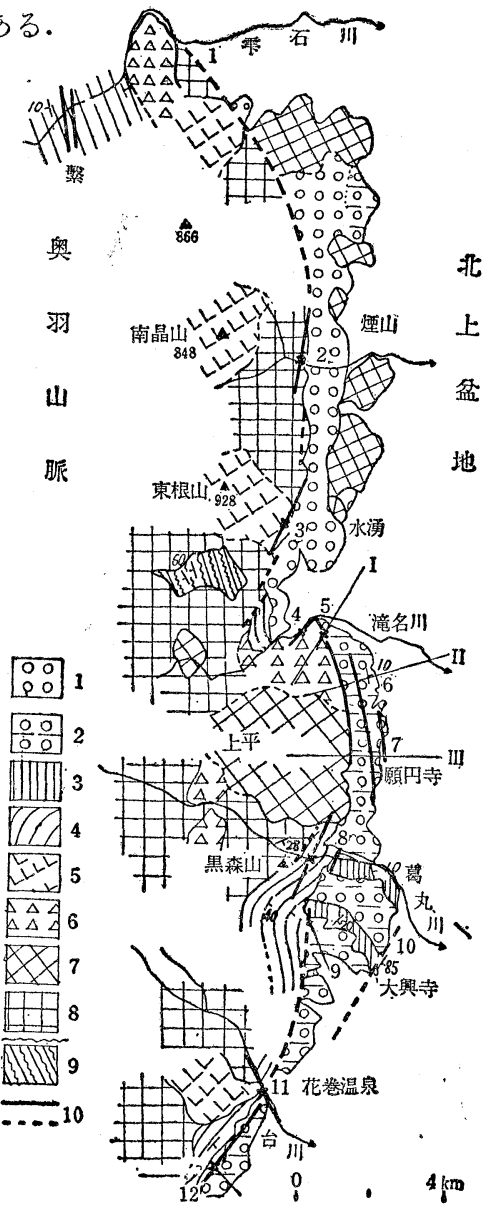

第 1 図奥羽山脈東縁部の地質図

1. 䃯層 2 . 志知層 3 . 大興 寺累層 4. 高井沢累層 5 . 石 英安山岩・石英粗面岩 6 . 安山 岩質集塊岩 7 . 輝石安山岩 8 緑色㠜兏岩・角䂺岩 9 . 基盤岩

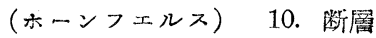


40〜 $50 \mathrm{~cm}$ の灰白色凝灰質砂岩と頁岩の規則的互層が夕られ，乙てでは西 へ 60〜80 傾々ているが，南部では東へ傾く.グリーン・タフとは黒森山 の北, 花巻温泉花盛館の裏手の崖などで整合している. 岩相や上下の層 底的関係から夕て黑沢尻地域の中新統，菱内層(6)飞対比できよう。な㧅山 地の北部に登達する葉層理の著しい凝灰質砂岩は, 大体同じ層準と思らが, 滰名川溪口のものはまだ疑問の点もある.

[大興寺霓層]大興寺の西方で，上述の累層を不整合に被ら軟弱な砂泥 と砂岩の互層は，10 数枚の亜孷を挾夕，また多量の浮石を混元，ク口ス・ ラミナの発達が著しい，地層驻西又は東へ 10 ～ $20^{\circ}$ 傾いているが，東部へ 来て傾斜をまし丘陵の東端では垂直となり，北上盈地へ没している。と扎 らは臓田延男(6)の鮮新統，荒谷層とよく似ている.

[志和層】上平の東辺には，4〜5枚の亜炭を挾む博かい砂泥や砂礫の

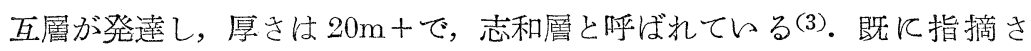
れているが(2)，願円寺附近の本畨から出る Menyantes trifoliasa $L$ は, 更 新世後を(9) J 3 期示与層準である. 花卷温泉南方飞発達する垔孷を挾む砂 泥及び砂礫の互層も, 岩相, 砂礫の種類, 固結の程度から志和層に対比で をると思う。亲祘, 最近, 煙山村一帯の天然ガス田の報告によれば(7), 地 表より $100 \mathrm{~m}$ 位まで博弱な地層が存在するといらが，洪積統及び第 3 系等 の埋没したものと推定される.

[火成岩類] 各種の火成岩が岩株, 岩脈をなして分布し, グリーン・タ フを貫いているが，相互の噴出順序は不明である，注意すべきは，南晶山 の東辺に分布する輝石安山岩が，黒色緻密で玄武岩とよく似ているとと及 びそれからなる孤立丘の南北方向の配列である.

3, 断屬の野外資料とその解釈 調查の零石川以北と以南の一部を除い て, 北から順にのべる.

南晶山断層 南晶山 (848m) の東麓, 「北の沢」の出合附近 (loc.2) そ, グリーン・タフををるN $12 \mathrm{E} ， 80^{\circ} \mathrm{W}$ 破砕带（ $5 \sim 6 \mathrm{~m} ）$ があり，断層粘 土は $30 \mathrm{~cm}$ 位西る。地形飞対する関係から逆断層と思ら。他の場所では断 層面をみていないが，北部の loc.1附近ではグリーン・ダフが著しくもめ ている.ての崖（高さ $500 \mathrm{~m}$ ) と東の孤立丘との間には緩斜面があり，高

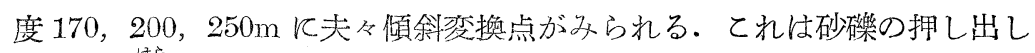
による「原地形」(8)と思われる。たとえば第1図のA(飯岡野), $170 \mathrm{~m} の$ 变換点附近では，西から押し出した径 50 〜 $80 \mathrm{~cm}$ 大のグリーン・タフや安 
山岩礫が明らかに下位の面を被い，堆積末端はかなり急に終つている。ま た, loc. 2 の北方（諏訪神社の北）の小谷には径 1〜 $3 \mathrm{~m}$ 大の円い輝石安 山岩磁が夕られる，その北の道路の切割では，新旧の碟層が被覆関係を示 して未り，上位の礫層には径 $1 \mathrm{~m}$ 安山岩や流紋岩との他が混つて和り， 泥土もかなり大つている.

東根山 $(928,4 \mathrm{~m})$ の東斜面は第 2 図に見る通りで，×印（水分神社） の裹に石英安山岩 を $2 \mathrm{~m}$ 位破砕する $\mathrm{N} 40^{\circ} \mathrm{E}, 52^{\circ} \mathrm{E} の$ 断層がある. 破砕 帯からは多量の地 下水がふを出し, 絶える事がないと いわれる.との崖

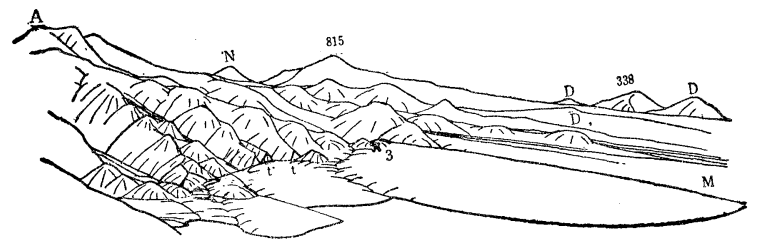
第 2 図東根山東斜面 A：東根山 $\mathrm{N}$ ：南晶山 $\mathrm{D}$ ：輝石安山岩よりなる 小丘 $\mathrm{T}$; 未端面

の南方，大沢出合附近飞も地形・地質ふら大体似た走向の断層が推定され る.な打第 2 図, loc. 3 東方の扇状地形の表面には, 高度 $200,220,250,2$ $80 \mathrm{~m}$ 等に傾斜の変換線があり, 扁平なレンズを重ねをような地形である. 最上位の面には径 50 70 cm 大の石英安山岩の角磉が散乱している. 原面 はほとんど曲折されていない. 上述の資料から，南晶山東辺の崖は断層に 起因寸る地形である. 崖の新鮮さ, 断層運動と関係したらしい堆積地形汃 ら久て新期の運動であろら。

上下断層 第 1 図と 3 の loc.5の露頭については既に報等が两るが(2)， 筆者の資料を加える. (1) loc. 5 の志和層流, 下位の集塊岩層の上K $\mathrm{N} 50 \mathrm{~W}$, $20^{\circ} \mathrm{W}$ をつて重な り, 附近の集塊岩層 \& $\mathrm{N} 20^{\circ} \mathrm{W}, 38^{\circ} \mathrm{W}$ で 東へ傾斜 ${ }^{(2)}$ していな レ.とてで崖錐をほ り，志和層ををる $\mathrm{N}$

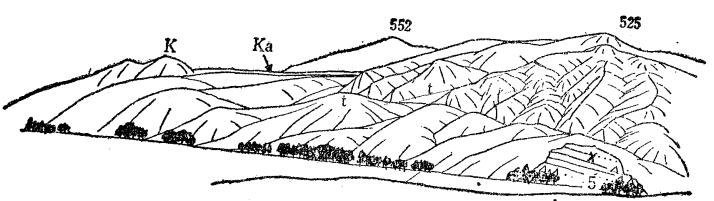

第 3 図上平北東部

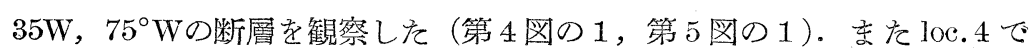
は上述の集塊岩層は東へ $35^{\circ}$ 傾くから，4 45 の間に断層が通るらしい.

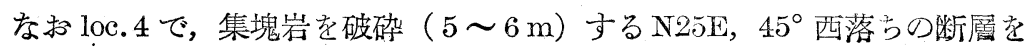
みた。 
（2）和山の北，北大沢に沿ら道路で夕た砂泥とそれを被ら集塊岩層 （菓へ $10^{\circ}$ 傾く）壳断面図にかき込むと第 4 図のII となり，孤立丘の西側 に断層が推定される。凉打和山北部の洪積層からなる平坦地形面(2)の上に, 径 $2 \mathrm{~m}$ 位の安山岩の磁を夕るととがある.

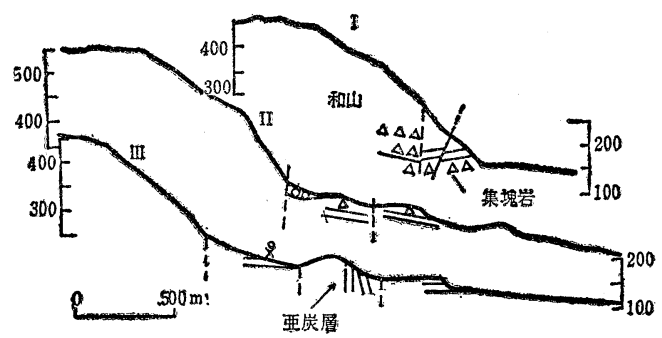

第4図上平北東方の断面図（第 1 図参照）

F : Menyantaes tri foliata $\mathrm{L} の$ 産地

(3) 願円寺 (loc.7) 西 方の 2 つの小丘は南北飞並 び，附近の地層は 5 〜 $10^{\circ}$ 東へ傾斜しているが，小丘 の西側には凹地列があり， 附近定断層が通るらしい. まを願円寺の南, 隠里寺西 南の沢で注粘土層が $\mathrm{N} 25 \mathrm{~W}$, $55^{\circ} \mathrm{E}$ 走し，上流では垂直 となる（第 4 図のIII）．乙れらの資料は階段断層の予想(1)(2)を裏書きする であろら. 即占志和層からなる 3 列, 20 数筒の孤立群注階段断層による のである. 断層面は夕られないが，大体垂も直に近いと思う。

黒森山断層 北部に比べると断層地形は不明瞭であるが，黒森山（414， $6 \mathrm{~m})$ の東辺に注数籄所に断尿が露出している. 第 5 図の上図は, 黒森山 から東へのびる尾根を東西にをつた模式断面を北からみたもので，右側は 山地側觉示す. 斨面図に記大の 2 ～ 5 はスケッチの番号である. 2 は第 1 図の×印（loc.8）の断層で， N $18^{\circ} \mathrm{E} ， 80^{\circ} \mathrm{W}$ を示し $20 \mathrm{~cm}$ 位破砕してい

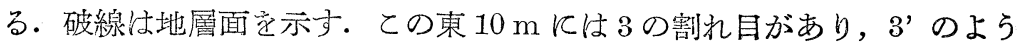
に考えられるので，斜め上下の方向に引張りの㗢いたてとを表わしている. 更に数的東に 4 があり，西方へ引曳されたてとを示している．また尾根の 裏側にらがあり，ててで東（図の左）へ傾いていた地層が，小断層を介し て急にむき西へ変えているととは地層転位の一型式として注目される。 断面図の斜線の部分は転位の大をな場所を示す，以上から，断層面 2 の東 側の地層が西方に大規模に引曳されたととが明らかである。な和その他の 場所，たとえば第1図の9でもスケッチに示したよらな小断層がみられる れだけでは精しいととはわからない。また黒森山でも，グリーン・タフが が，乙部分的に破磁・変質しており断層が推定される。

上記の諸断層の生成の時期は，断層を直接被ら新期堆積物をかくが，断 層の規模, 断層地形の不明瞭等から夕ると洪積世以前のものと思ら. 大興 
寺の loc. 10 附近では, 丘陵菒崖 $\mathrm{N}$ が $30^{\circ} \mathrm{E}$ K 走り，そてで地層が直立し，東側には露出し ないので断層が通ると推定される.

草井山断層 草井山 (413.2 m) 北方の孤 立丘の西側 (loc.12) K，第5 図のスケッチ 7 に示した洪積層をきる断層がある。地層は 軟らかい砂泥と砂碟からなり, 間飞覀宸層

（80cm）を挾む。断層は $\mathrm{N} 28 \mathrm{E} ， 20^{\circ} \mathrm{W}$ の衝 上で，層間異常ではない. 露頭の東は $\mathrm{col}$ に なつている.ての北方には，第 6 図に夕るよ らな小丘が大体 $\mathrm{N} 30^{\circ} \mathrm{E}$ 亿並んでいる．盽層 によるケルンバルトと考元られる。な和孤立 丘Kは洪積層からなり，地層は東へ $20 \sim 40^{\circ}$ 傾いている. 台川溪口の loc. 11 では, $50^{\circ}$ 東 一傾く凝兏質砂岩層ををる N $30 \mathrm{~W} 65^{\circ}$ 北東 落ちの斜交断層が数本久られる. その他, loc. 11 と 12 及び草井山東辺部については調查し ていない. 以上から, 後者の率層活動の時期 は決められ孛いが，前者は洪積户堆積後と言 える.

\section{4 結論 考察の結果を要約すれば}

（1）上平，草井山両断層恃洪積層 $\mathrm{J}_{3}$ 堆 積後生成したもので, 南晶山断層も既にのへ た理由から同時期である.

（2）黒森山断層は洪積世堆積前の8ので ある.一般に断層面は急傾斜で，とくに南晶 山東面の断層, 黒森（loc.8）罙どは逆断層 と判断される. しかし断層の機構的解釈学行 らには未だ資料が不十分である。

また，山地の東辺に和いて，屢々地層が大 をな転位を示すととがあるが，てれらの原因 が断層運動の結果であるのか，あるいは，第 3 番の下部に潜在する基盤運 動を反映した一種の撓曲運動の結果なのか，とれらの点については現在の 


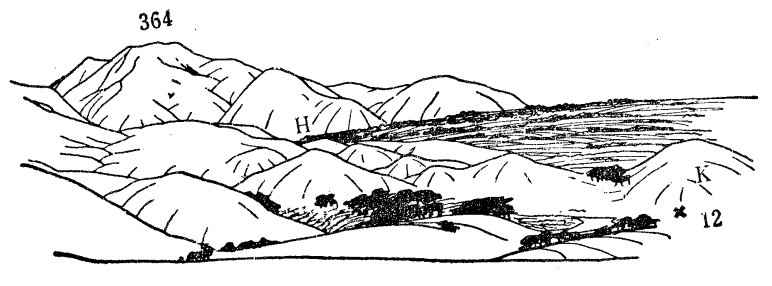

第6 図 草井山加万北望

$\mathrm{H}$; 花巻温泉 $\mathrm{K}$; ケルンバット
ととろ不明である。

要するに盛岡断層群

は，北上盆地成立の 一要素として重要で あり，その運動纺第 3 紀末加方委続く 構造運動の一環と解 釈される。（1954 年 11 月 21 日受理)

\section{参考 文 献}

1. 辻村太郎; 断層地形論考. (1942) 108～147. 2. 富田芳郎：岩手県北上平野 西縁去限る上平断䁲崖の地形. 地評. 24 (1951) 37. 3. 早川典久: 岩手県奥羽 山地東縁部の地体構造に関する一考察. 岩磺, 35，5 (1951) 140〜145. 4. 山根 新次 : 盛岡図幅地質説明書. (1914) $19 . \quad 5$. 村山賢一：横手地質説明書. (1937) 2. 6. 藏田延男: 仙人䟔・黒沢尻間の第 3 紀層. 石油技協誌, Vol. 9 ([1941) 7. 舟山裕土 : 岩手罧紫波郡煙山村天然ガス調查報告畫, 地質調査所月報, 2 (195 1） 8. 三野与吉 : 伊那谷の地形. 地評， $24 ， 7$ (1951) $5 \sim 10.9$. 鹿間時夫 : 第四紀. (1952) 23.

\section{ON THE MORIOKA FAULT GROUP, IWATE PREFEECTTRE}

\section{Shirō KANEKo}

(1) The conspicuous fault topographies, as terminal facets, kernbuts and kerncols, Hara topography were observed on the eastern foots of the Mt. Nan. shō, Azumane and Uwandaira as shown in Fig. 1,2 and 3.

(2) The geologic evidences related to these fault were found at the locations 1 12 in Fig.1, 4, 5. The fault planes generally dip to the west. The Mt. Kuromori fault and. Mt. Nanshō fault seem to be high angle reverse faults. (3) The age of the faulting are classified in two periods: the one may be Post-Shiwa bed (pleistocene), and the other Pre-Shiwa bed. The Mt. Nanshō, Mt. Uwandaira and Mt. Kusai faults belong to the former, and Mt. Kuromori fault to the latter.

In brief, the Morioka fault group played an important role in the formation of the Kitakami basin, and its movement took placed in recent age. 